Красинский Владислав Вячеславович

доктор юридических наук, полковник, член экспертной группы

по международному антиэкстремистскому сотрудничеству

при МИД России

\title{
Противодействие использованию террористическими организациями каналов миграции и вовлечению граждан России в террористическую деятельность за рубежом
}

Ключевые слова: миграция, террористическая организация, незаконное вооруженное формирование, вооруженные конфликты, вовлечение в террористическую деятельность.

Аннотащия: автор анализирует проблему использования каналов миграции членами террористических организаций, исследует зарубежный опыт пресечения миграции боевиков и оценивает возможности рецепции передовой зарубежной практики применительно к российским условиям.

Keywords: migration, terrorist organization, illegal armed formation, armed conflicts, involvement in terrorist activities.

Abstract: The author analyzes the problem of migration channels which are using by members of terrorist groups. He also explores international experience of militants migration suppression and evaluates the possibility of advanced foreign practice application in the Russian Federation.

Источник опубликования: Красинский В.В. Противодействие использованию террористическими организациями каналов миграции и вовлечению граждан России в террористическую деятельность за рубежом // Современное право. 2017. № 2. С. 88-93.

Военная операция ВКС России на территории Сирийской Арабской Республики, усилия международной антитеррористической коалиции в Сирии и Ираке активизировали попытки террористов перенести свою деятельность за пределы Ближневосточного региона. Кроме того, успехи сирийской армии привели к росту дезертирства в террористических группировках и вызвали волну возвращения иностранных боевиков на их родину. Российская Федерация с рядом других государств постсоветского пространства стала рассматриваться лидерами 
«мирового джихада» в качестве одной из приоритетных целей для террористических атак ${ }^{1}$.

В значительной степени этому способствует то, что, по имеющимся сведениям, в вооруженных конфликтах на Ближнем Востоке на стороне экстремистов принимают участие около 10 тысяч выходцев из стран бывшего $\mathrm{CCCP}^{2}$, треть из которых составляют граждане России. Только в Сирии в боевых действиях участвуют свыше 30 различных террористических группировок, большая часть которых укомплектована выходцами из Северо-Кавказского и Приволжского федеральных округов Российской Федерации. В числе этих структур батальоны «Джохар Дудаев», «Шамиль Басаев» и «Амир Хаттаб». Несложно оценить деструктивный потенциал такого количества хорошо подготовленных боевиков, сплоченных религиозно-экстремистской идеологией.

Возможность их возвращения в страны исхода для целенаправленного совершения террористических актов представляет серьезную угрозу национальной безопасности. «Возвращенцы» обладают навыками обращения с оружием, изготовления взрывчатых веществ и взрывных устройств, знанием тактических приёмов ведения боевых действий, радикальными взглядами и многочисленными связями в криминальной среде. Кроме того, данная категория лиц выполняет роль модераторов и идейных проводников исламистского радикализма, участвует в вербовке и переправке рекрутов в лагеря подготовки боевиков и зоны вооруженных конфликтов ${ }^{3}$. В Российскую Федерацию эмиссары-вербовщики проникают с использованием миграционных и туристических потоков, а после оседания и легализации начинают вести активную работу внутри диаспор выходцев из Центральной Азии, в российских регионах с преобладанием мусульманского населения. Мононациональная обособленность, правовая беспомощность, влекущая за собой социальную дискриминацию и унизительную

${ }^{1}$ В начале октября 2015 г. войну России объявили такие террористические группировки, действующие в Сирии, как «Армия Ислама» («Дейш аль-Ислам») и «Джебхат ан-Нусра». 14 октября 2015 г. пресс-секретарь «Исламского государства» объявил о начале джихада против России.

2 По оценке генерального секретаря Совета коллективной безопасности государствучастников ОДКБ Н. Бордюжи.

${ }^{3}$ Поздняков А. И. Транснациональный терроризм как средство геополитики // Вестник Национального антитеррористического комитета. 2014. № 2(11). С. 95-103. 
зависимость от своих работодателей, обусловливают успех рекрутированию мигрантов в ряды международных террористических организаций (далее - МТО). Идеологической основой вербовки в, как правило, является религиозно экстремистская догматика, увязанная с идеями социальной справедливости.

Установлено, что большинство вернувшихся в Россию боевиков по заданию главарей международных террористических группировок вступает в ряды бандгрупп, действующих на Северном Кавказе. Одним из условий возвращения боевиков из зоны сирийского конфликта является прохождение ими дополнительной снайперской или минно-взрывной подготовки и принятие обязательств по дальнейшему участию в террористической деятельности. По возвращении на родину такие лица нередко меняют установочные данные и место жительства, создают законспирированные ячейки и приступают к подготовке террористических актов. Другая часть боевиков, получивших боевой опыт террористической деятельности за рубежом, как уже отмечалось, становится вербовщиками в ряды МТО.

В этих условиях особую актуальность приобретает своевременное выявление в миграционных потоках на стадии пересечения государственной границы участников террористических структур. Работа осложняется не только огромным количеством мигрантов, пересекающих границу России (ежегодно около 20 млн иностранцев), но и из-за применяемых ими ухищрений, среди которых наиболее распространено использование поддельных паспортов или документов, выданных на вымышленные имена. Регулярно фиксируются попытки въехать в Российскую Федерацию через границы государств-участников СНГ. Одновременно в России действуют подпольные лаборатории, специализирующиеся на изготовлении фиктивных документов, необходимых как для выезда из нашей страны, так и для легализации на ее территории.

Законодательством Российской Федерации предусмотрен комплекс организационно-правовых мер, связанных с недопущением проникновения на территорию Российской Федерации членов МТО и вовлечения российских граждан в террористическую деятельность за рубежом. Реализация данной системы мер в целом позволяет контролировать ситуацию на каналах миграции, 
нейтрализовывать попытки проникновения членов МТО и экстремистских объединений в Российскую Федерацию и пресекать транзит рекрутов в зоны вооруженных конфликтов.

Совместными усилиями российских спецслужб и правоохранительных органов вскрыты основные каналы выезда радикальных исламистов с территории России в международные лагеря подготовки боевиков и маршруты их возвращения. Определены «транзитные страны», через территорию которых перемещаются рекруты (Турция, Ливия, Египет, Грузия, Азербайджан, Украина, Беларусь, Иран и страны Центральноазиатского региона).

В пунктах пропуска через государственную границу Российской Федерации налажен механизм выявления и фильтрации лиц указанной категории в ходе прохождения ими пограничного контроля. Пограничными органами осуществляется их фотографирование, дактилоскопия и, по возможности, отбор генетических образцов.

Во взаимодействии с иностранными партнерами на основании информации ФСБ России осуществляется своевременное закрытие въезда в «транзитные страны» граждан России, собирающихся или уже участвующих в деятельности террористических организаций. Аналогичная работа проводится в отношении лиц, пытающихся въехать на территорию России для участия в террористической деятельности на территории Северо-Кавказского региона и других субъектов РФ.

Ведутся перечни запрещенных террористических и экстремистских организаций, участники которых преследуются в уголовном порядке.

Принимаются меры по пресечению контрабанды оружия и иных средств поражения с территории зарубежных государств, в первую очередь из стран Прибалтики, а также Украины, Абхазии и Южной Осетии.

Росфинмониторинг проводит работу по вскрытию и пресечению источников и каналов финансирования международных террористических организаций и аффилированных с ними лиц.

Можно констатировать, что в Российской Федерации в целом создана правовая база противодействия международному терроризму и противодействия миграции боевиков. Введена ответственность за организацию деятельности 
террористической организации и создание террористического сообщества. Ужесточено наказание за организацию незаконного вооруженного формирования и участие в нем. Криминализированы участие в вооруженных конфликтах за рубежом в составе МТО, вербовку рекрутов в интересах МТО и обучение террористической деятельности.

Несмотря на достигнутые положительные результаты, следует признать, что основные проблемы, которые не позволяют поставить надежный заслон террористам, стремящимся использовать для проникновения на территорию России каналы миграции, остаются прежними. Среди них:

незавершенность договорно-правового оформления значительных участков Государственной границы Российской Федерации с государствами-участниками СНГ и их техническая необустроенность;

проявления коррупции в субъектах государственной миграционной политики; упрощенный порядок въезда на территорию Российской Федерации граждан некоторых иностранных государств;

несовершенство системы миграционного учета и контроля за въездом, выездом и пребыванием иностранных граждан и лиц без гражданства на территории Российской Федерации.

Имеются определенные пробелы и в правовом регулировании миграционных процессов, что умело используется членами террористических группировок. Так, законодательство практически не регламентирует миграционные потоки из государств-участников СНГ с безвизовым въездом или упрощенным порядком оформления въездных виз, что позволяет гражданам этих стран беспрепятственно въезжать и оседать на постоянное жительство в Российской Федерации.

В Федеральном законе «О миграционном учете иностранных граждан и лиц без гражданства в Российской Федерации» не предусмотрена обязанность принимающей стороны уведомлять миграционные органы об убытии иностранного гражданина из адреса, что позволяет мигрантам бесконтрольно перемещаться по территории России. 
Ключевой характеристикой правового регулирования миграционных отношений в контексте противодействия использованию каналов миграции международными террористическими и экстремистскими организациями выступает степень регламентации порядка привлечения к административной и уголовной ответственности за нарушение миграционного законодательства России.

Действующее законодательство не регулирует порядок задержания, привлечения к административной ответственности и выдворения из Российской Федерации иностранных граждан и лиц без гражданства, не имеющих при себе документов, удостоверяющих личность. Зная о существовании временных ограничений по установлению личности (не более 3 часов) и практике отказа судей рассматривать дела об административных правонарушениях без подтверждения личности правонарушителя, иностранцы могут уклониться от наказания, спрятав свои документы.

Правовая база позволяет нелегальным мигрантам уклоняться от уголовной ответственности, предусмотренной ст. 322 УК РФ «Незаконное пересечение Государственной границы Российской Федерации» в случае задержания не по месту незаконного пересечения границы.

Отсутствуют механизмы привлечения к ответственности лиц, выдворенных из Российской Федерации и не имеющих разрешения на въезд, в случае замены документов, удостоверяющих личность, с изменением установочных данных.

Все это существенно осложняет деятельность спецслужб и правоохранительных органов по контролю за выездом и возвращением граждан из регионов повышенной террористической активности и зон вооруженных конфликтов, выявлению и пресечению деятельности лиц, подозреваемых в причастности к международным экстремистским структурам и террористическим организациям.

Исходя из изложенного, представляется целесообразным строить работу по противодействию участникам международных террористических структур, использующих для проникновения на территорию Российской Федерации каналы миграции, в направлении совершенствования правового регулирования 
миграционных отношений и укрепления взаимодействия с уполномоченными федеральными органами исполнительной власти в сфере миграции.

В целях противодействия вербовочной работе МТО и экстремистских структур следует расширять практику обмена информацией с зарубежными партнерами. Необходимо поддерживать взаимодействие в части установления планов террористов, получения установочных данных боевиков и их пособников, добывания оперативно значимой информации о схемах их заброски, каналах финансирования, применяемых методах агитации и вербовки.

Еще одним из перспективных направлений взаимодействия национальных и зарубежных правоохранительных органов может стать организация совместной работы по выявлению и ликвидации опорной и транзитной инфраструктуры боевиков, пресечению устойчивых каналов миграции террористов.

Для совершенствования российского опыта нейтрализации угроз безопасности, связанных с проникновением на территорию Российской Федерации членов МТО и вовлечением российских граждан в террористическую деятельность за рубежом, можно использовать не противоречащие законодательству Российской Федерации нормативные решения иностранных правотворческих органов и передовую зарубежную правоприменительную практику.

В настоящее время с целью повышения эффективности противодействия вербовочной деятельности МТО и выезда лиц для обучения в лагерях подготовки боевиков и последующего участия в вооруженных конфликтах за рубежом власти ряда государств ужесточают национальное антитеррористическое законодательство ${ }^{1}$. В частности, в Австралии приняты поправки к закону «О гражданстве» (Citizenship Act), в соответствии с которыми лица, имеющие двойное гражданство и подозреваемые в причастности к терроризму, лишаются австралийского гражданства и подлежат депортации из страны ${ }^{2}$.

${ }^{1}$ Mercer P. Unease Grows over New Australian Dual Citizenship Rules // BBC. 2015. June 1. В 2015 г. в Конституцию Республики Таджикистан были внесены поправки, предусматривающие лишение гражданства в качестве наказания за присоединение к международным экстремистским объединениям и зарубежным экстремистским организациям.
${ }^{2}$ Australian
Citizenship
Act
[электронный
pecypc]

https://www.legislation.gov.au/details/C2006C000317 (дата обращения - 22.04.2016). 
В январе 2015 г. Парламентом Великобритании был принят закон «О борьбе с терроризмом и обеспечении безопасности» (Counter-Terror and Security Act 2015), который предусматривает временный запрет на въезд в Великобританию лиц, подозреваемых в причастности к терроризму за границей ${ }^{1}$. Основой запрета является судебное постановление о временном воспрепятствовании (на срок до 24 месяцев) во въезде в страну лиц, подозреваемых в терроризме (Temporary Exclusion Order). Эта мера реализуется путем внесения подозреваемых в терроризме в список «недопускаемых к авиаполетам лиц» и изъятия паспортов на пунктах пограничного контроля. Лица, въезжающие в Великобританию, в случае подозрений в причастности к террористической деятельности могут быть подвергнуты допросу и временному задержанию².

Сотрудникам полиции и пограничной службы предоставляется право изымать на границе паспорта и билеты британских подданных сроком на 30 суток, если органы власти обоснованно подозревают указанных лиц в намерении участвовать в террористической деятельности за пределами Великобритании или в том, что они ранее прибыли на территорию Соединенного королевства для последующего выезда за ее пределы в террористических целях.

Судебный запрет на въезд может быть продлен по представлению руководства МВД Великобритании. Попытка несанкционированного въезда в страну в нарушение действующего законодательства влечет за собой лишение свободы на срок до 5 лет.

Министр внутренних дел с целью предупреждения терроризма вправе издавать приказы о высылке из страны лиц, имеющих отношение к совершению, подготовке или подстрекательству к террористической деятельности.

Законом также предусмотрена возможность изъятия паспортов британских подданных, не достигших 18-летнего возраста, при попытке выезда в регионы повышенной террористической активности (Афгано-пакистанская зона, Сирия, Ирак).

\footnotetext{
${ }^{1}$ Counter-Terror and Security Act 2015 [электронный pecypc] https://www.gov.uk/government/ publications/factsheet-counter-terrorism-and-security-bill (дата обращения - 22.04.2016).

${ }^{2}$ Институты конституционного права / Под ред. Л.В. Андриченко, А.Е. Постникова. М.: ИЗИСП при Правительстве РФ, 2013.
} 
В Законе Французской Республики 2014 г. «О борьбе с терроризмом» содержится запрет лицам, подозреваемым в террористической деятельности и планирующим участие в вооруженных конфликтах за рубежом, покидать территорию государства.

В США на каналах въезда-выезда применяется не менее жесткая практика миграционного контроля и фильтрации.

В Законе США «О национальной безопасности и регистрации въезда, выезда» 2004 г. выделена категория лиц «повышенного риска», в которую входят граждане стран с повышенной террористической активностью (Иран, Ирак, Ливия, Сирия и Судан). Эти лица при пересечении границы США подлежат обязательному фотографированию, дактилоскопированию и регистрации ${ }^{1}$.

Как мы видим, зарубежная практика правового регулирования допускает разнообразные юридические ограничения прав граждан и иностранцев в целях предупреждения террористической деятельности на территории государств и за ее пределами. Следует отметить, что эти ограничения устанавливаются как в судебном, так и в административном порядке.

Возможности рецепции российским законодателем зарубежного опыта требуют существенных оговорок.

4 декабря 2015 г. Конституционным Собранием Республики Дагестан в Государственную Думу Федерального Собрания Российской Федерации был внесен законопроект № 945490-6 «О внесении изменений в Федеральный закон «О гражданстве Российской Федерации» (в части введения процедуры лишения гражданства отдельных категорий граждан Российской Федерации). Законопроектом предусмотрено лишение гражданства в связи с участием граждан в боевых действиях на стороне МТО и осуществлением террористической деятельности в составе незаконных вооруженных формирований на территории иностранного государства в целях, противоречащих интересам Российской Федерации.

${ }^{1}$ Институты конституционного права / Под ред. Л.В. Андриченко, А.Е. Постникова. М.: ИЗИСП при Правительстве РФ, 2013. 
Данная инициатива не соответствует Конституции Российской Федерации, поскольку в силу ч.3 ст.6 никто не может быть лишен своего гражданства. В Российской Федерации не допускается лишение лица гражданства даже в качестве санкции за совершенное преступление. Как свидетельствует практика Конституционного Суда Российской Федерации (Постановление от 16 мая 1996 г. № 12-П по делу о проверке конституционности пункта «г» статьи 18 Закона Российской Федерации «О гражданстве Российской Федерации» в связи с жалобой А.Б. Смирнова), прекращение гражданства Российской Федерации возможно лишь по добровольному волеизъявлению гражданина в условиях свободного выбора.

Российская Федерация в контексте общепризнанных международных стандартов придерживается принципа предотвращения безгражданства: не допускается выход из гражданства Российской Федерации при отсутствии гарантий приобретения иного гражданства. Такой подход соответствует Конвенции 1961 г. о сокращении безгражданства.

Вместе с тем положения об обязательном дактилоскопировании, получении биологического материала и изъятии паспортов при попытке выезда граждан Российской Федерации в регионы повышенной террористической активности могут быть закреплены в федеральных законах от 25 июля 1998 г. № 128-Ф3 «О государственной дактилоскопической регистрации в Российской Федерации», от 15 августа 1996 г. № 114-Ф3 «О порядке выезда из Российской Федерации и въезда в Российскую Федерацию».

Учитывая, что пересекающие границу Российской Федерации члены МТО и их пособники, как правило, используют поддельные документы на чужие установочные данные или документы с измененными персональными данными, представляется целесообразным ввести обязательную государственную дактилоскопическую регистрацию всех иностранных граждан и лиц без гражданства (прибывающих в Российскую Федерацию, постоянно и временно проживающих на территории Российской Федерации, незаконно находящихся на 
территории Российской Федерации $)^{1}$. Данная мера позволит усилить контроль за пересечением Государственной границы и исключить возможность негласного проникновения в Российскую Федерацию лиц, причастных к деятельности МТО.

Заслуживает внимания возможность заимствования норм об административном выдворении иностранных граждан и лиц без гражданства, участвовавших в планировании, подготовке, подстрекательстве и пособничестве в террористической деятельности ${ }^{2}$.

Актуальными представляются выработка официальной позиции МИД России по вопросам участия боевиков-добровольцев в вооруженных конфликтах на территории Йемена, Афганистана и Пакистана, а также заключение международных договоров Российской Федерации с заинтересованными государствами по вопросам уголовного преследования осуществляющих террористическую деятельность иностранных граждан и лиц без гражданства, не проживающих постоянно в Российской Федерации, и привлечения указанных лиц к уголовной ответственности на территории Российской Федерации. Данные меры позволили бы квалифицировать действия лиц, находящихся за рубежом, осуществляющих склонение, вербовку, подготовку, вооружение граждан Российской Федерации для участия в террористической деятельности и вступления в ряды МТО, в качестве действий, направленных против интересов Российской Федерации. Применение к данным деяниям ч.3 ст. 12 УК РФ способствовало бы более эффективной борьбе с вовлечением российских граждан в террористическую деятельность за рубежом путем привлечения вербовщиков, пособников и участников незаконных вооруженных формирований к уголовной ответственности по ст. 205.1, 205.3, ч.2 ст. 208 УК РФ.

1 Это потребует внесения изменений в ст. 5 Федерального закона от 25 июля 1998 г. № 128-Ф3 «О государственной дактилоскопической регистрации в Российской Федерации» (перечень лиц, подлежащих государственной дактилоскопической регистрации, необходимо дополнить категорией «иностранные граждане и лица без гражданства, прибывающие в Российскую Федерацию, постоянно и временно проживающие на территории Российской Федерации, незаконно находящиеся на территории Российской Федерации») и корректировки ст. 9 (исключения пунктов «з»», «и», «К», «Л», «ПП», «р»)).

2 Административное наказание в виде выдворения за пределы территории Российской Федерации распространяется на иностранных граждан и лиц без гражданства, совершивших правонарушение в соответствии с КоАП РФ. Данное наказание назначается судом в качестве дополнительного. 
С учетом постоянного роста численности сторонников МТО и участников незаконных вооруженных формирований, действующих за рубежом, считаем целесообразным инициировать на законодательном уровне включение объявления официального предостережения о недопустимости действий, создающих условия для совершения преступлений, дознание и предварительное следствие по которым отнесено законодательством Российской Федерации к ведению органов федеральной службы безопасности, а также предостережения прокурора о недопустимости нарушения закона при наличии сведений о готовящихся противоправных деяниях с признаками террористической или экстремистской деятельности в перечень оснований для ограничения выезда российских граждан за пределы территории Российской Федерации.

В связи с этим ст. 15 Федерального закона «О порядке выезда из Российской Федерации и въезда в Российскую Федерацию» предлагается дополнить пунктом 3.1 следующего содержания: «является лицом, которому объявлено официальное предостережение о недопустимости действий, создающих условия для совершения преступлений, дознание и предварительное следствие по которым отнесено законодательством Российской Федерации к ведению органов федеральной службы безопасности, либо предостережение прокурора о недопустимости нарушения закона при наличии сведений о готовящихся противоправных деяниях с признаками террористической или экстремистской деятельности (при этом срок ограничения не может превышать пяти лет со дня объявления предостережения)».

Как представляется, дальнейшее совершенствование правового регулирования миграционных процессов, выработка единых подходов к юрисдикционной и предупредительно-профилактической практике на каналах въезда и выезда повысит эффективность работы спецслужб и правоохранительных органов по противодействию террористическим и экстремистским организациям. 